\title{
THE FRENCH SCHOOL OF ORGAN PLAYING IN ITS OWN LAND
}

\author{
By JEAN HURE
}

$I^{\mathrm{N}}$

$\mathrm{N}$ every land, even in the land of our late enemies, the talent of the French virtuosi is undisputed-hence it is superfluous to state that at the clarion call to arms all our interpreting artists, soloists or orchestra players proved themselves worthy of the reputation they have everywhere acquired. Nevertheless, they have made a special and quite unexpected step in advance. And this achievement in progress seems all the more foreign to the general preoccupations of our musical world owing to the fact that it has been effected in a sector of art in which France has already scored an incontestable superiority: that is to say in our school of organ playing, It is a matter which deserves closer study, and calls for an examination in retrospect.

It is an established fact that the art of organ playing was cultivated with particular splendor toward the close of the Middle Ages, during the Renaissance, the seventeenth century, and at the beginning of the eighteenth. And the foreign schools modelled themselves on French art in this field, the Italian school in particular, and afterward the German.

Yet in spite of the glory which is the portion of the Dane, Buxtehude; and of the Italians, Frescobaldi and Scarlatti, the fame of the organists of France was preponderant, even in Germany, during the youth of Johann Sebastian Bach. Bach freely acknowledged himself to be a disciple of 'Iitelouze, of Couperin, and of Nicholas de Grigny, as well as of Buxtehude, Pachelbel and Frescobaldi.

Had it been possible, at the cost of study and patient endeavor to equal or even surpass the French masters in the art of fugue and counterpoint (and at that none could surpass Titelouze and Roberday in their own day), no musician of any land could attain, either as a virtuoso player or composer, the spirit, charm, grace, good taste and delicacy of a Couperin or a Clérambault; the imaginative power and depth of a Nicholas de Grigny.

Organ technic at that time was not, what so many too often suppose, a matter of transferring to the organ keyboard the technic of the clavichord. Various documents attest this, among others 


\section{The French School of Organ Playing in its Own Land 273}

the pages in which André Raison has set down a complete theory of organ playing, pointing out the different modes of attack which might utilize the various tone colors of the organ to advantage.

Johann Sebastian Bach was well versed in this finished technic: we have every reason to believe that he used it marvellously well himself. Händel, on his part, astonished the Italians by his triumphs on the pedals, ${ }^{2}$ which he played with greater mastery than Scarlatti, despite the probability that he was inferior to the latter as far as playing the manuals was concerned.

By reason of their real inspiration, and above all owing to a power for hard work and to a patience which French and Italians too often lacked, Johann Sebastian Bach and his disciples, toward the end of the 18th and at the beginning of the 19th century, created in Germany an organ school justly preferable to others. Yet, little by little, the French tradition vanished, became Germanized. It was entirely natural that this should be the case in Germany; but how regrettable it is that France herself was subjected to a neo-German influence which Johann Sebastian Bach would have disavowed. He was but little understood, incidentally, in Germany at the beginning of the 19th century; and in France he was looked upon as an obscure composer, a pure savant, invariably grandiose and solemn, void of charm, spirit and inspiration. (The dictionaries, in particular that of Larousse, up to the end of the 19th century, established this fact).

It was a period when one could say publicly, without shocking anyone:

The Catholic organist draws his inspiration from God. He endeavors to convince, touch and persuade; he makes his instrument pray. The Protestant organist, on the other hand, is dependent on himself for his inspiration. His harmonies do not represent a naïve and simple prayer; nor are they the outcome of inspiration. They stand for a combination of chords varying in richness, discovered with labor and research. In one word they represent Art, and nothing more. So much for Bach and his imitators. (Lemmens's words at the Congress of Malines, 1863)

It was by this school, so evidently opposed to the art of Bach, that our French organists were formed-to play Bach crudely and heavily was known as "having the Bachian tradition." Besides, the organists of that day hardly knew the works of the French

1The superiority of Handel and that of his contemporaries in Germany with regard to pedal playing has been largely exaggerated. One finds in Nicholas de Grigny various pedal passages more difficult to play than any which may be met with in the works of Händel, and even of Buxtehude. Only in the music of Johann Sebastian Bach is it possible to find virtuose examples of the same kind. 
organists of the 17th and 18th centuries. They only played Bach, with registrations and phrasings which made his music as monotonous and tiresome as possible; they played Mendelssohn and compositions of their own, as a rule imitations of what these great masters had written.

The exact knowledge and the need for clarity inherent in the French temperament had happily inclined them to observe the cult of clean-cut execution. In this respect they excelled every other school in the world; yet in the name of respect for a suppositious Germanic tradition, they insisted on regarding the boresome as the primordial law of organ playing. It was in vain that some true lovers of charm in whom, almost despite themselves, the traditional genius of the French race survived, revolted against the crudeness and heaviness in execution imposed upon them. Such were Boëly, Chauvet, Saint-Saëns, obsessed by the lightning-like playing of Liszt; the meditative César Franck, with his genius for improvisation, Gigout, full of imagination, ingenuity and skill; Boëllmann, the dreamer, who died so prematurely. In vain Guilmant, with the aid of his pupil, the historian Pirro, edited the organ books of the French School; the solemn and aggressive state of boredom persisted. The organ was still played with implacable neatness, and the whole art of playing was resumed in rudely beating the manuals in an absolutely uniform manner, without regard for the stops employed or the character of the work executed. The organ was not "played," it was literally "beaten," to use the expression of an excellent musician.

Rare indeed were those among our young virtuosi, ${ }^{1}$ who had the courage to protest against this injurious technic and its incomplete and objectionable perfection.

It now seems as though, without losing its qualities of clarity and firmness, our French School of organ playing is about to resume its traditional character, which appeared to have been lost for all time.

Under the influence of Eugène Gigout ${ }^{2}$ appointed professor at the Paris Conservatory some ten years ago, our younger organists have once more discovered the true Bachian tradition and, something especially precious from our point of view, the true French tradition. Their touch, their manner of playing has grown supple and varied, capable of firmness, even of rigidity; when needs be, of violence or tenderness. Their rhythmic

'The best known among them is Joseph Bonnet, a pupil of Guilmant.

'Franck, in his Musica Sacra wrote: "Eugène Gigout is a great, a very great organist, and a most astonishing improvisor." 
The French School of Organ Playing in its Own Land 275

exposition has grown more flexible; they have gained much in intelligence and variety of phrasing. Their registrations betray taste and avoid monotony, they improvise fugues with as much perfection as before, but with more imagination. Finally, they are allowed-and this license is astounding on the part of a master born in 1844-to branch out into a modernism which some might find extreme, yet which is always interesting, and which gives the organistic art an entirely new physiognomy.

It may be hoped, therefore, that under whis beneficent influence, the art of organ playing, too long restricted to the Church, and too often looked upon as tiresome and repelling, may become a familiar feature in concert and chamber music-hall throughout the world. If so, France again will have taken the lead in a great musical movement.

(Translated by Frederick H. Martens) 